\title{
Studies on Fatigue of Night Duty Workers at a Newspaper Office
}

\author{
Masanobu FUJII' ${ }^{1)}$, Tamotsu MIYOSHI ${ }^{2)}$ \\ and Tadataka FUKUI ${ }^{3)}$
}

\author{
1) School of Medical Sciences, The University of Tokushima, 18-15, Kuramoto- \\ cho, Tokushima 770, Japan \\ 2) Department of Public Health, School of Medicine, The University of \\ Tokushima, 18-15, Kuramoto-cho, Tokushima 770, Japan \\ 3) The Preventive Arteriosclerosis Research Association, Ohtebiru, 3-19-7, \\ Toranomonn, Minato-ku, Tokyo 105, Japan
}

(Received October 26, 1995 and in revised form January 19, 1996)

\begin{abstract}
Fatigue of night duty workers in different divisions of a newspaper office was investigated by physiological methods such as the Blinker, Flicker and grip methods. The relationship between fatigue and hematological parameters such as hemoglobin $(\mathrm{Hb})$, the hematocrit (Ht), serum-free amino acid levels, and indices of liver function such as the GOT and GPT levels were also examined. The composing and press room workers mainly complained of the subjective symptom of muscle fatigue, while workers in the photoengraving and editorial departments mainly complained of mental fatigue. The overall rate of fatigue in the newspaper office was about $38.1 \%$, but varied from one division to another, being especially high in the photo-engraving and editorial departments. The subjects with fatigue had low levels of serum GOT and GPT and high levels of serumgluconeogenic amino acids, such as aspartic acid, glutamic acid, prolin, glycine, and alanine. These altered levels of serum-free amino acids and GOT and GPT seemed to be due to increased secretion of adrenal corticoid hormone caused by the stress of fatigue.
\end{abstract}

Key words: Fatigue - Blinker - Flicker - Grip - Serum-free amino acid - Liver function test

\section{INTRODUCTION}

To prevent accidents and increase work efficiency at work sites, it is important to evaluate fatigue due to work and eliminate the causes.

As fatigue is not easy to evaluate directly, it is usually evaluated indirectly as a decrease in labor efficiency ${ }^{1)}$ and a decrease in the Flicker value, which physi-

Correspondence to: School of Medical Sciences, The University of Tokushima, 18-15, Kuramoto-cho, Tokushima 770, Japan 
ologically ${ }^{2)}$ indicates the level of brain excitation or alterations of blood and urine components that maintain homeostasis under normal conditions ${ }^{3)}$.

In this study, we investigated the fatigue of night duty workers at a newspaper office by conducting physiological tests and by measuring blood components. Then we compared the values obtained by these procedures.

\section{Materials ANd Methods}

\section{Subjects and their work divisions}

Twenty-one healthy men between the ages of 24 and 42 were included in this study. Of these men, seven were in the editorial department, seven in the composing room, two in the photo-engraving department, four in the press room and one in the forwarding department.

\section{Work in each division}

The stream of work processes from pressing to publication at a newspaper office involves various types of work. The editorial department workers select newspaper items, arrange the spacing, and proofread the sheets. Work in the composing room includes type-picking, type-setting, and making-up the paper. The photo-engravers take photographs and make photo-plates. Work in the press room involves blocking from type printing, preparing the lead plate, and pressing. The forwarding workers send off the pressed newspaper. In the editorial department, work is almost all sedentary, whereas work in the pressing and forwarding departments involves working while standing. These processes are carried out in day and night shifts, and all the subjects in this study were on night shifts. The study was carried out for nine days from Dec. 11 to Dec. 19, 1983.

As shown in Table 1, all the divisions, particularly the press, photo-engraving and forwarding departments, have different and irregular working hours.

\section{Fatigue evaluations}

Investigations of the subjective symptoms of fatigue

The subjective symptoms of fatigue were investigated at the beginning and the end of each work period based on a Japanese Table entitled Survey of Subjective Symptoms of Fatigue ${ }^{4)}$.

\section{Measurements of Blinker, Flicker and grip values}

Blinker (B), Flicker (F) and grip (G) values were measured using a Fukui Blinker measuring instrument ${ }^{3)}$, Ohshima Flicker measuring instrument ${ }^{3)}$ and Smedori-type hand dynamometer ${ }^{3)}$, respectively. Three measurement were taken with each of these instruments every night, one at the beginning, one in the middle, and one at the end of the shift. To evaluate fatigue, the daily and weekly variations of the $\mathrm{B}, \mathrm{F}$ and $\mathrm{G}$ values were calculated using the equations shown below. 
Table 1. Times of work of employees in different divisions at a newspaper office.

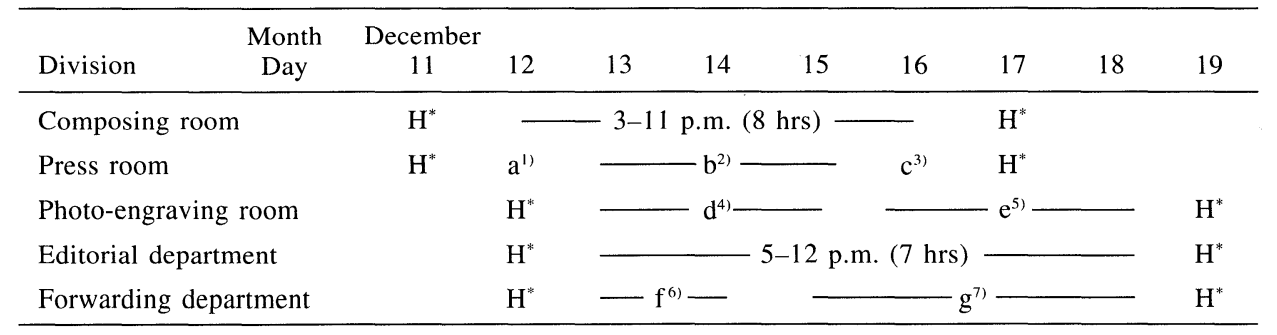

* Holiday

1) 9 a.m. until 3 p.m. (6 hrs). Early attendance for an evening paper.

2) 7 p.m. until 4 a.m. (9 hrs). A morning paper.

3) 1 p.m. until 6 p.m. ( 5 hrs). Late attendance for an evening paper.

4) 3 p.m. until 11 p.m. (8 hrs).

5) 11 a.m. until 7 p.m. ( 8 hrs).

6) 9 p.m. until 4 a.m. (7 hrs).

7) 9 a.m. until 5 p.m. (8 hrs).

When both the daily and weekly variations of two of the three items showed negative values and the weekly variatios were larger than the daily variations, the individual was evaluated as suffering from fatigue ${ }^{2}$.

Daily variation $(\%)=$ (value after work on the day after a holiday/value before work on the day after a holiday x 100) - 100

Weekly variation $(\%)=($ value before work on the last day before a holiday/value before work on the day after a holiday x 100) - 100

\section{Blood examinations and liver function tests}

Blood examinations and liver function tests were performed twice a night, once at the beginning and once at the end of each shift. Blood was collected from an antecubital vein of subjects before their breakfast. The specific gravity $(\mathrm{Gb})$, hemoglobin $(\mathrm{Hb}, \mathrm{g} / \mathrm{dl})$, hematocrit $(\mathrm{Ht}, \%)$, and serum total protein level (TP, g/ $\mathrm{dl}$ ) of the blood were recorded. $\mathrm{Gb}, \mathrm{Hb}, \mathrm{Ht}$ and $\mathrm{TP}$ were measured by the copper sulfate, cyanometohemoglogin, capillary tube, and protein refractor methods, respectively.

After serum separation, indices of liver function, such as the levels of aspartate transferase (GOT), alanine aminotransferase (GPT), and total cholesterol (TC), and the results of the zinc turbidity test (ZTT) and the thymol turbility test (TTT) were analyzed using a kit for liver function tests (Tsugai Drug Co.) and a spectrophotometer.

\section{Serum-free amino acids}

Serum was separated by the method described by Stein \& Moor ${ }^{5)}$, and the serum 
levels of free amino acids were measured using a Yanagimoto LC-5s amino-acid analyzer.

\section{Investigation of nutritional intake}

The food eaten by each subject on days 3 and 4 of the study period was noted, and nutritional intake was calculated using Standard Tables of Food Composition in $\operatorname{Japan}^{6}$.

\section{RESULTS}

\section{Subjective symptoms of fatigue}

The subjective symptoms of fatigue were classified into three groups (I, II, III $)^{4}$. Group I was used to investigate sleepiness and languor. Composing room workers had a high rate of eye-weariness $(55.0 \%)$, tiredness of the legs $(43.3 \%)$ and sleepiness $(43.3 \%)$; press room workers complained of tiredness of the legs $(83.3 \%)$, eye-weariness $(60.0 \%)$, and loss of concentration $(50.0 \%)$; photo-engraving room workers complained of eye-weariness $(85.7 \%)$, tiredness of the legs $(71.4 \%)$, and dullness of the body (42.9\%); editorial department workers complained of eyeweariness $(67.9 \%)$, tiredness of the legs $(37.5 \%)$ and yawning $(33.9 \%)$.

Group II was used to investigate the difficulty of focusing one's attention. Complaints by workers in the photo-engraving room and editorial department were more common than in the composing and press departments. For example, photoengraving room workers complained of having no time to rest during work (21.4\%), feeling irritable $(14.3 \%)$, and being unable to concentrate $(11.2 \%)$, while editorial department workers complained of a loss of patience $(26.8 \%)$, a loss of unenthusiasm (19.7\%), and an inability to remember details $(14.3 \%)$.

Group III was used to investigate definite physical irrelevancy. Press room workers mainly complained of a dry mouth (60.0\%), stiff shoulders $(50.0 \%)$, and back pain $(30.0 \%)$; editorial department workers complained of stiff shoulders $(51.8 \%)$, a dry mouth (39.3\%), and a twitching of the eyelids and muscles $(16.1 \%)$.

Thus, there was some difference in the complaints of workers in the different divisions. The subjective symptoms of composing and press room workers, that is, tiredness of the legs, an inability to rest during work, a dry mouth and stiff shoulders seemed mainly due to muscle fatigue. However, the complaints of workers in the photo-engraving room and editorial department, that is, eye-weariness, an inability to concentrate, and stiff shoulders seemed mainly due to mental fatigue.

\section{Result of fatigue investigations}

The relationships of the calculated daily and weekly variations of the B, F and $G$ values of the 21 subjects are shown in Figure 1 (B), Figure $2(F)$, and Figure $3(\mathrm{G})$. 


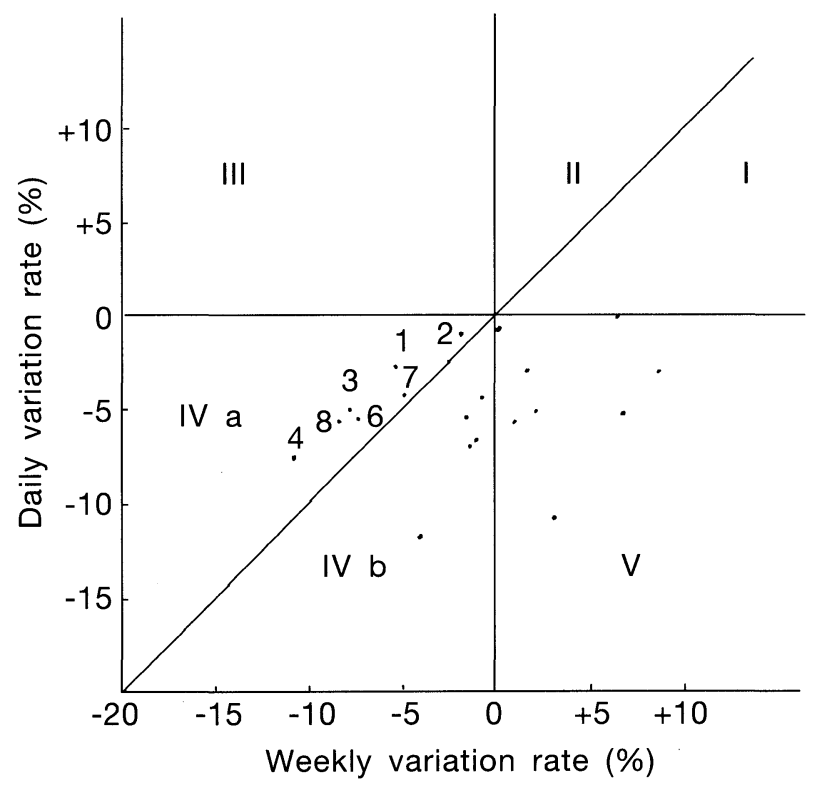

Fig. 1. Relation between daily and weekly variation rates of Blinker values.

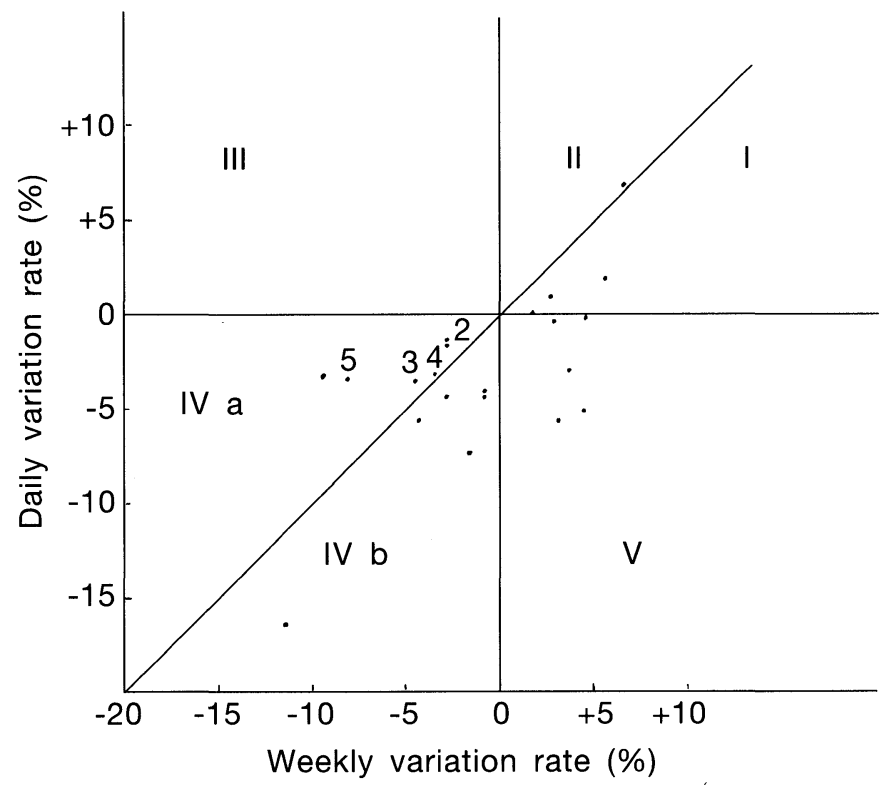

Fig. 2. Relation between daily and weekly variation rates of Flicker values. 


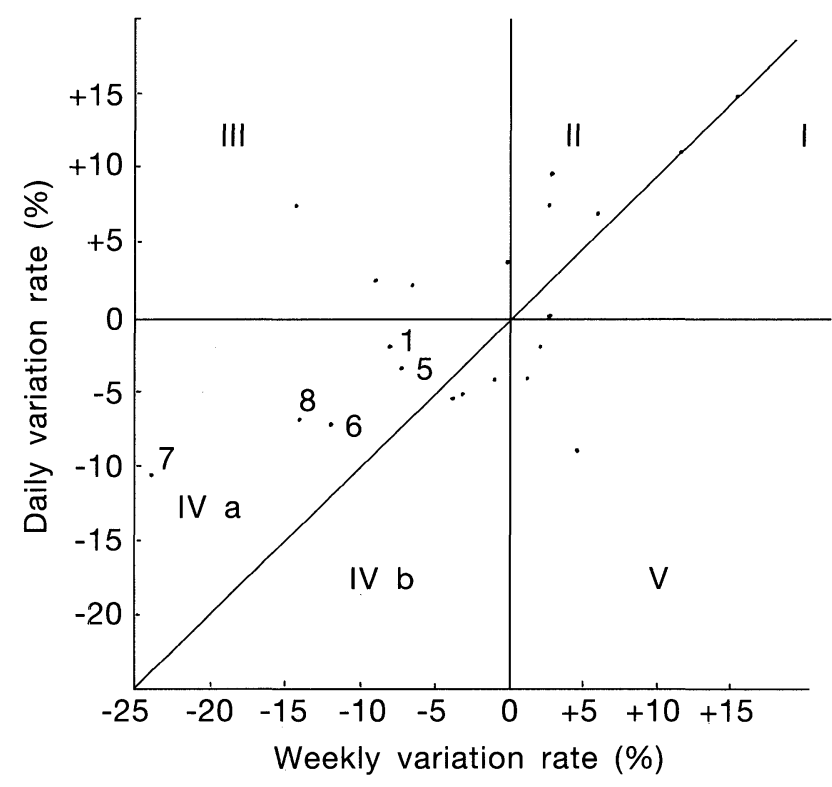

Fig. 3. Relation between daily and weekly variation rates of grip values.

The regions marked IV a indicate that both the daily and weekly variation rates were negative, and weekly variations were more radical than daily variations. When values for two of the three items were within the IV a region, the subject was considered to be in a state of fatigue ${ }^{2)}$. By this method, eight of the 21 subjects (numbers 1 to 8 ) were considered to be suffering from fatigue. The two items in region IV a were $B$ and $G$ for subjects $1,6,7$ and $8, B$ and $F$ for subjects 2,3 and 4 , and $F$ and $G$ for subject 5 . The numbers of subjects with fatigue and their appearance rates in the photo-engraving room, editorial department, composing room and press room were two (100\%), three $(42.9 \%)$, two $(28.6 \%)$, and one $(25.0 \%)$, respectively, indicating higher values in the photo-engraving room and editorial department.

\section{Hematological findings and liver function tests}

Table 2 shows the hematological findings and the results of liver function tests in groups with and without fatigue, and of those groups before work. The GOT and GPT values of the group with fatigue were much lower than those of the values before work, the GPT values of the two groups with fatigue being significantly different from the values before work $(\mathrm{p}<0.05)$. Values for parameters, such as $\mathrm{Ht}$ and TC were not essentially different before and after work.

\section{Serum-free amino acids}

Table 3 shows the serum levels of essential amino acids in the two groups and 
Table 2. Hematological data on night duty workers at a newspaper office.

\begin{tabular}{|c|c|c|c|c|c|c|c|c|c|}
\hline & \multicolumn{5}{|c|}{ Liver function tests } & \multicolumn{4}{|c|}{ Blood examinations } \\
\hline & $\begin{array}{c}\text { GOT }^{\prime \prime} \\
\text { Karmen } \\
\text { Unit }\end{array}$ & $\begin{array}{c}\mathrm{GTP}^{2)} \\
\text { Karmen } \\
\text { Unit }\end{array}$ & $\begin{array}{c}\text { TTT }^{3)} \\
\text { Maclagan } \\
\text { Unit }\end{array}$ & $\begin{array}{c}\mathrm{ZTT}^{4)} \\
\text { Kunkel } \\
\text { Unit }\end{array}$ & $\begin{array}{c}\mathrm{Tc}^{7)} \\
\mathrm{mg} / \mathrm{dl}\end{array}$ & $\mathrm{Gb}^{6)}$ & $\begin{array}{l}\mathrm{Hb} \\
\mathrm{g} / \mathrm{dl}\end{array}$ & $\begin{array}{c}\mathrm{HT} \\
\%\end{array}$ & $\begin{array}{l}\mathrm{TP}^{7)} \\
\mathrm{g} / \mathrm{dl}\end{array}$ \\
\hline \multicolumn{10}{|l|}{$\begin{array}{l}\text { No fatigue } \\
\text { group }^{8)}\end{array}$} \\
\hline Before work & $\begin{array}{c}14.7 \\
( \pm 5.0)\end{array}$ & $\begin{array}{c}19.6 \\
( \pm 6.1)\end{array}$ & $\begin{array}{c}2.20 \\
( \pm 0.53)\end{array}$ & $\begin{array}{c}6.8 \\
( \pm 1.6)\end{array}$ & $\begin{array}{c}171.3 \\
( \pm 31.0)\end{array}$ & $\begin{array}{c}1.058 \\
( \pm 0.002)\end{array}$ & $\begin{array}{c}14.8 \\
( \pm 1.7)\end{array}$ & $\begin{array}{c}46.9 \\
( \pm 2.4)\end{array}$ & $\begin{array}{c}7.6 \\
( \pm 0.5)\end{array}$ \\
\hline After work & $\begin{array}{c}14.2 \\
( \pm 3.8)\end{array}$ & $\begin{array}{c}19.2 \\
( \pm 5.7)\end{array}$ & $\begin{array}{c}2.18 \\
( \pm 0.61)\end{array}$ & $\begin{array}{c}6.6 \\
( \pm 1.8)\end{array}$ & $\begin{array}{c}164.4 \\
( \pm 28.4)\end{array}$ & $\begin{array}{c}1.058 \\
( \pm 0.003)\end{array}$ & $\begin{array}{c}14.6 \\
( \pm 1.1)\end{array}$ & $\begin{array}{c}46.3 \\
( \pm 2.6)\end{array}$ & $\begin{array}{c}7.7 \\
( \pm 0.5)\end{array}$ \\
\hline \multicolumn{10}{|l|}{ Fatigue group ${ }^{9)}$} \\
\hline Before work & $\begin{array}{c}14.9 \\
( \pm 4.7)\end{array}$ & $\begin{array}{c}19.4^{*} \\
( \pm 5.8)\end{array}$ & $\begin{array}{c}2.24 \\
( \pm 0.49)\end{array}$ & $\begin{array}{l}6.8 \\
( \pm 1.9)\end{array}$ & $\begin{array}{c}168.8 \\
( \pm 42.7)\end{array}$ & $\begin{array}{c}1.058 \\
( \pm 0.003)\end{array}$ & $\begin{array}{c}15.0 \\
( \pm 1.0)\end{array}$ & $\begin{array}{c}46.7 \\
( \pm 2.8)\end{array}$ & $\begin{array}{c}7.5 \\
( \pm 0.5)\end{array}$ \\
\hline After work & $\begin{array}{c}11.4 \\
( \pm 5.0)\end{array}$ & $\begin{array}{c}14.4 \\
( \pm 2.1)\end{array}$ & $\begin{array}{c}2.83 \\
( \pm 1.15)\end{array}$ & $\begin{array}{c}6.9 \\
( \pm 1.4)\end{array}$ & $\begin{array}{c}181.3 \\
( \pm 51.5)\end{array}$ & $\begin{array}{c}1.059 \\
( \pm 0.002)\end{array}$ & $\begin{array}{c}15.8 \\
( \pm 1.4)\end{array}$ & $\begin{array}{c}45.2 \\
( \pm 3.1)\end{array}$ & $\begin{array}{c}7.4 \\
( \pm 0.4)\end{array}$ \\
\hline \multicolumn{10}{|c|}{ 1) Aspartate aminotransferase. } \\
\hline \multicolumn{10}{|c|}{ 2) Alanine aminotransferase. } \\
\hline \multicolumn{10}{|c|}{ 3) Thymol turbidity test. } \\
\hline \multicolumn{10}{|c|}{ 4) Zinc turbidity test. } \\
\hline \multicolumn{10}{|c|}{ 5) Total cholesterol. } \\
\hline \multicolumn{10}{|c|}{ 6) Specific gravity of blood. } \\
\hline \multicolumn{10}{|l|}{ 7) Total protein. } \\
\hline \multicolumn{10}{|c|}{ 8) Means \pm SD for 13 subjects. } \\
\hline \multicolumn{10}{|c|}{ 9) Means \pm SD for 8 subjects with fatigue carried over to next day. } \\
\hline \multicolumn{10}{|c|}{ * Significantly different from values of after work of fatigue group by matched pairs $t$-test $(\mathrm{p}<0.05)$. } \\
\hline \multirow[t]{3}{*}{$\begin{array}{l}\text { Table } 3 . \\
\text { office. }\end{array}$} & \multicolumn{9}{|c|}{ Serum free essential amino acids of night duty workers at a newspaper } \\
\hline & \multicolumn{5}{|c|}{ No fatigue group ${ }^{1)}(\mathrm{mg} / \mathrm{dl})$} & \multicolumn{4}{|c|}{ Fatigue group $^{2)}(\mathrm{mg} / \mathrm{dl})$} \\
\hline & & efore worl & & After wor & & Before wor & & After $w$ & vork \\
\hline Threonine & & $.58 \pm 0.63$ & & $2.50 \pm 0.7$ & & $2.57 \pm 0.5$ & & $2.66 \pm$ & 0.57 \\
\hline Valine & & $60 \pm 1.11$ & & $4.60 \pm 1.2$ & & $4.58 \pm 1.2$ & & $4.58 \pm$ & 0.72 \\
\hline Cystine & & $.55 \pm 0.26$ & & $1.53 \pm 0.2$ & & $1.53 \pm 0.3$ & & $1.58 \pm$ & 0.31 \\
\hline Methionine & & $41 \pm 0.17$ & & $0.40 \pm 0.1$ & & $0.38 \pm 0.1$ & & $0.39 \pm$ & 0.11 \\
\hline Isoleucine & & $60 \pm 0.87$ & & $1.59 \pm 0.5$ & & $1.58 \pm 0.6$ & & $1.51 \pm$ & 0.21 \\
\hline Leucine & & $61 \pm 0.79$ & & $2.62 \pm 0.8$ & & $2.59 \pm 0.5$ & & $2.64 \pm$ & 0.44 \\
\hline Tyrosine & & $.79 \pm 0.49$ & & $1.79 \pm 0.6$ & & $1.83 \pm 0.6$ & & $1.87 \pm$ & 0.37 \\
\hline Phenylalanine & & $.78 \pm 0.47$ & & $1.71 \pm 0.5$ & & $1.76 \pm 0.7$ & & $1.91 \pm$ & 0.28 \\
\hline Lysine & & $29 \pm 0.38$ & & $3.40 \pm 0.4$ & & $3.32 \pm 0.5$ & & $3.20 \pm$ & 0.57 \\
\hline Means $\pm \mathrm{SD}$ & & $25 \pm 1.81$ & & $2.24 \pm 1.5$ & & $2.24 \pm 1.8$ & & $2.26 \pm$ & 1.62 \\
\hline
\end{tabular}

1) Means \pm SD for 13 subjects.

2) Means \pm SD for 8 subjects with fatigue carried over to next day. 
in those groups before work. There were no significant differences in the values before and after work.

Table 4 shows the kinds of nonessential amino acids in these same groups. The levels of aspartic acid, glutamic acid, proline, glycine, and alanine were higher in the group with fatigue than in the group without fatigue, the difference in the levels of aspartic acid and glutamic acid being significant $(\mathrm{p}<0.05)$.

\section{Nutritional intake}

Table 5 showed the nutritional intakes of the groups with and without fatigue. The intakes of calcium and vitamin $\mathrm{A}$ of both groups were lower than the nutritional allowance, but the nutritional allowances for other nutrients were satisfied. The vitamin $\mathrm{C}$ intake of the group without fatigue was significantly higher than that of the group with fatigue $(\mathrm{p}<0.05)$.

\section{DisCUSSION}

Workers in a newspaper office have various jobs, such as collecting news, selecting news, editing, composing, and pressing.

In this study, we evaluated the fatigue of night shift workers in various departments of a newspaper office via physiological methods, then compared the results with hematological findings.

The daily variation rate can be determined from the $B, F, G$ values before and after work. But hard work on the previous day and a short period of sleep are reported to increase the daily variation rate and cause errors in evaluating fatigue ${ }^{2)}$.

Table 4. Serum free non-essential amino acids of night duty workers at a newspaper office.

\begin{tabular}{|c|c|c|c|c|}
\hline & \multicolumn{2}{|c|}{ No fatigue group ${ }^{\prime \prime}(\mathrm{mg} / \mathrm{dl})$} & \multicolumn{2}{|c|}{ Fatigue group $^{2)}(\mathrm{mg} / \mathrm{dl})$} \\
\hline & Before work & After work & Before work & After work \\
\hline Aspartic acid & $0.58 \pm 0.27$ & $0.56 \pm 0.26$ & $0.56 \pm 0.26$ & $0.83 \pm 0.21^{*}$ \\
\hline Serine & $2.28 \pm 0.43$ & $2.21 \pm 0.60$ & $2.31 \pm 0.62$ & $2.33 \pm 0.40$ \\
\hline Glutamic acid & $2.87 \pm 1.52$ & $2.96 \pm 1.95$ & $2.85 \pm 1.94$ & $5.23 \pm 2.24^{*}$ \\
\hline Proline & $3.51 \pm 1.61$ & $3.57 \pm 1.50$ & $3.49 \pm 0.97$ & $3.85 \pm 0.79$ \\
\hline Glycine & $2.78 \pm 0.73$ & $2.77 \pm 0.67$ & $2.80 \pm 0.55$ & $3.36 \pm 0.85$ \\
\hline Alanine & $5.18 \pm 1.68$ & $5.24 \pm 1.76$ & $5.16 \pm 1.53$ & $6.23 \pm 1.22$ \\
\hline Histidine & $1.12 \pm 0.33$ & $1.15 \pm 0.21$ & $1.16 \pm 0.25$ & $1.19 \pm 0.37$ \\
\hline Arginine & $1.51 \pm 0.28$ & $1.53 \pm 0.35$ & $1.49 \pm 0.38$ & $1.30 \pm 0.19$ \\
\hline Means $\pm S D$ & $2.48 \pm 1.86$ & $2.50 \pm 0.35$ & $2.47 \pm 1.91$ & $3.04 \pm 2.03$ \\
\hline
\end{tabular}

1) Means \pm SD for 13 subjects.

2) Means \pm SD for 8 subjects with fatigue carried over to next day.

* Significantly different from values of before work of fatigue group by matched pairs $t$-test $(\mathrm{p}<0.05)$. 
Table 5. Nutritional intakes of night duty workers at a newspaper office.

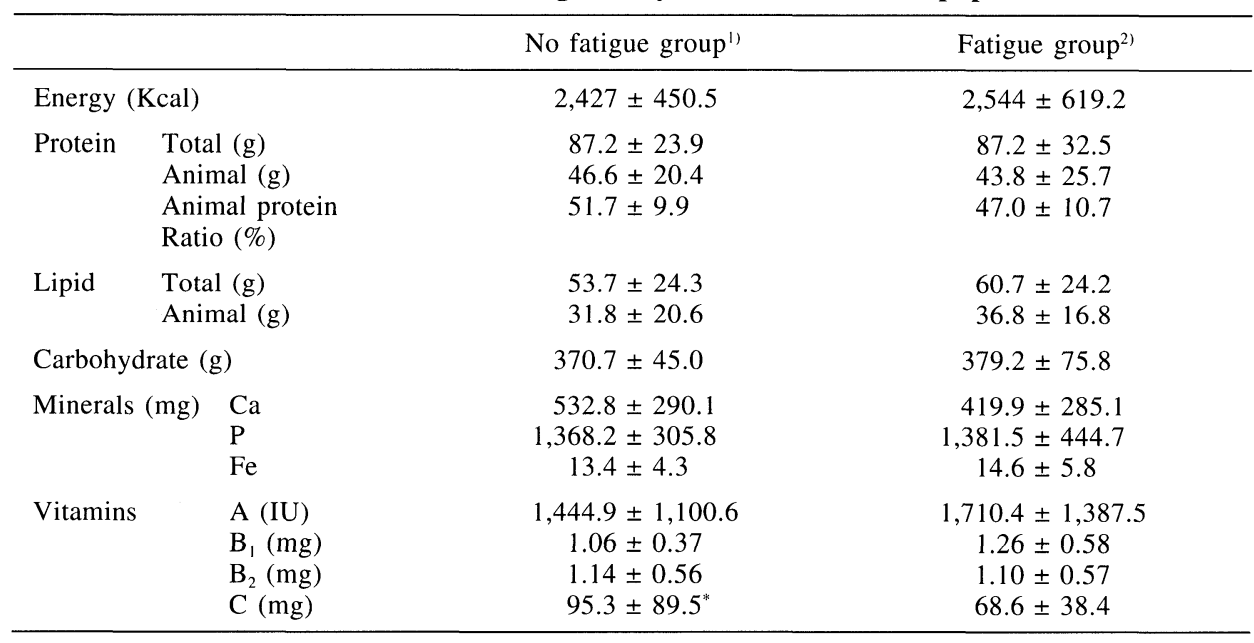

* Significantly different from value of group with fatigue by $t$-test $(\mathrm{p}<0.05)$.

1) Means \pm SD for 13 subjects.

2) Means \pm SD for 8 subjects with fatigue carried over to next day.

Therefore, in this study, we determined the variation rate the day after a holiday. A larger weekly variation rate than the daily variation rate is reported to indicate fatigue, which is carried over to the next day ${ }^{2)}$. This fatigue is believed to occur mainly in the case of mental work. In this study, the rate of appearance of fatigue was $38.1 \%$ for all subjects, and was higher among workers in the photoengraving room $(100 \%)$ and editorial department $(42.9 \%)$ than among workers in other divisions. Moreover, an investigation of subjective fatigue showed that many workers in the photo-engraving room and editorial department suffered from mental fatigue.

Previous reports have already evaluated fatigue on the basis of alteration in blood and urine components ${ }^{1)}$. Therefore, in this study, we divided the subjects into groups with and without fatigue by using physiological methods, and then compared hematological findings in the two groups. In most cases in this study, fatigue resulted from mental work. We found that in the group with fatigue the serum levels of the gluconeogenic amino acids (proline, glycine, and alanine), and especially aspartic acid and glutamic acid, were significantly higher than those in the group without fatigue.

The levels of gluconeogenic amino acids are known to increase during protein degradation in a state of protein malnutrition ${ }^{7,8)}$, and to be regulated by hormones such as adrenal corticoid and insulin ${ }^{9}$.

Recntly, based on Serie's stress theory, various attempts have been made to evaluate fatigue on the basis of the defence reactions of the body caused by the stress of fatigue $^{10)}$. In the case of fatigue due to mental work, the secretion of glucocorticoid 
hormones is known to increase as a defence reaction of the body ${ }^{1,10,11)}$.

As the administration of adrenal corticoid hormone is known to cause an increase in serum amino acids ${ }^{12,13}$, and especially gluco-neogenic amino acids, it is possible that the secretion of adrenal corticoid hormone increases as a result of mental fatigue, leading to increased serum levels of amino acids. In contrast, Arakawa ${ }^{14)}$ found that in case of acute muscle fatigue, the serum levels of gluconeogenic amino acids, such as aspartic acid, glutamic acid and arginine decrease. Probably in case of acute muscle fatigue, free amino acids, as well as carbohydrates and lipids, are utilized for energy production via the TCA cycle ${ }^{15}$. We found no significant differences in the intakes of nutrients such as proteins or in the energy intakes of groups with and without fatigue that could explain the differences in their serum amino acid levels.

The levels of serum GOT and GPT are reported to be altered by physical exercise $^{16)}$ and nutritional intake ${ }^{17)}$, as well as by abnormal liver function. Their levels are thought to increase as a result of their leakage from cells, especially following inflammation that increases membrane permeability ${ }^{18)}$. Adrenal corticoid hormone is considered to block the leakage of these enzymes from cells by decreasing membrance permeability.

The results of our studies suggest that during the stress of mental fatigue, the serum levels of GOT and GPT decreased as a result of the increased secretion of adrenal corticoid hormone. We can also conclude that the serum levels of free amino acids are useful indices of mental fatigue.

\section{REFERENCES}

1) Saito H. Biochemical aspects of fatigue, with special reference to physical and mental burdens of work. J Science of Labour 1966; 42: 427-47 (in Japanese).

2) Ohshima M. Studies of fatigue. Tokyo: Dobun Shoin, 1945; 65-73 (in Japanese).

3) Kirihara H. Functional tests of fatigue evaluations. Tokyo: Nippon Sangyo Eisei Kyokai, 1967; (in Japanese).

4) Nippon Sangyo Eisei Kyokai. Report of a survey of subjective symptoms of industrial fatigue. Rodo no Kagaku 1970; 25(6): 12 (in Japanese).

5) Stein WH, Moore S. The free amino acids of human blood plasma plasma. J Biol Chem 1954: 211: 915-26.

6) Resources Council, Science and Technology Agency, Japan. Standard Tables of Food Composition in Japan, 4th ed. Tokyo: Daiich Syuppan, 1983; 18 (in Japanese).

7) Marian ES, Stewart GT. Plasma amino acid levels of men fed diets differing in protein content. Some observations with valine-deficient diets. J Nutr 1968; 88: 239-48.

8) Young VR, Scrimshaw NS. Endogenous nitrogen metabolism and plasma free amino acids in young adults given a 'protein-free' diet. Br J Nutr 1968; 22: 9-20.

9) Henry AL, David OF, Jerry WY, Earl S, Paul DR. Hormnal control of enzymes participating in gluconeogenesis lipogenesis. J Cell Comp Physiol 1965; 66: 39-53.

10) Yokobori S, Miyasaka T, Shiraishi A. Fatigue and adrenal cortex. Sangyo Igaku 1960; 2(5): 387-95 (in Japanese).

11) Suzuki I, Nishizaki R, Saito H. Biochemical studies on the effect of long term night shift (Report 1) - On the urinary excretion of 17-hydroxy corticosteroids and $\mathrm{Na} / \mathrm{K}$ and $\mathrm{Cl} / \mathrm{Na}$ ratios of urine —. J Science of Labour 1964; 40(12): 587-92 (in Japanese). 
12) Kaplan SA, Nagareda Shimizu CS. Effect of cortisol on amino acids in skeletal muscle and plasma. Endocrinology 1963; 72: 267-72.

13) Joseph JB, Muriel F, Philip F. The differential effects of glucocorticoid on tissue and plasma amino acid levels. Biochim Biophys Acta 1965; 104: 92-7.

14) Arakawa K, Fujioka R. Blood ammonia and amino acids in acute physical fatigue. Tekkou Roudou Eisei 1963; 12: 123-7 (in Japanese).

15) Krebs HA. Manometric determination of L-aspartic acid and L-asparagine. Biochem J 1950; 47: $605-14$.

16) Schlang HA, Kirkpatrick CA. The effect of physical exercise on serum transaminase. Am J Med Sci 1961; 242: 338-41.

17) Awapara J. Effect of protein depletion on the transaminating activities of some rat organs. J Biol Chem 1952; 200: 537-41.

18) Takeda Y, Ichihara A. Mechanism of enzyme excretion from cells. In: Akabori S, Okinaka S, eds. Rinsyou Kousogaku. Tokyo: Asakura Shoten, 1964; 7-10 (in Japanese). 